\title{
Upwelling, downwelling, and cross-shelf transport of bivalve larvae: test of a hypothesis
}

\author{
Alan L. Shanks*, Laura Brink \\ University of Oregon, Oregon Institute of Marine Biology, PO Box 5389, Charleston, Oregon 97420, USA
}

ABSTRACT: Larval supply affects the structure of marine communities. Cross-shelf transport of larvae by upwelling and downwelling may cause variation in larval supply. We tested the hypothesis that slowswimming bivalve larvae are swept offshore during upwelling and shoreward during downwelling. We sampled a transect at Duck, North Carolina during a period when currents shifted from upwelling to downwelling and back to upwelling. During each shift, nearshore water was exchanged with offshore water and currents were 10 to 100 times faster than larval swimming speeds. Larval Spisula solidissima and Ensis directus were found below the thermocline and, contrary to prediction, were swept onshore during upwelling and offshore during downwelling. When $S$. solidissima larvae were found above the thermocline, cross-shelf transport was as predicted. Larval Tellina spp. and Mulinia lateralis remained within $5 \mathrm{~km}$ of shore despite cross-shelf currents and the exchange of nearshore waters with offshore waters. They did not behave as passive particles; they were not swept offshore by upwelling or onshore by downwelling. For these taxa the hypothesis was rejected. These larvae may have remained close to shore by using behaviors analogous to those displayed by animals concentrated at convergent fronts. Given the relatively slow swimming speed of bivalve larvae, there is no reason to expect that any larval type is swept offshore by upwelling. The effect of upwelling and downwelling on larval distributions varies with larval behavior and vertical distribution. Without careful sampling, one cannot invoke offshore transport of larvae by upwelling as a cause of variations in larval settlement.

KEY WORDS: Larval dispersal - Larval transport · Oceanography · Supply-side ecology · Bivalve larvae · Downwelling

Resale or republication not permitted without written consent of the publisher

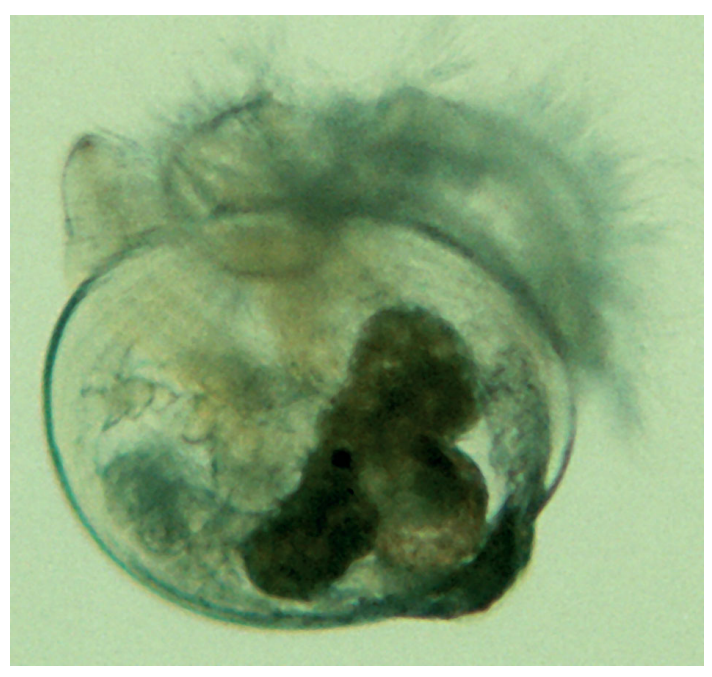

A typical bivalve veliger (a slow swimming larva). According to the current paradigm, larvae should be swept offshore by coastal upwelling and onshore by downwelling. We observed that bivalve larvae of some taxa remained near the coast despite upwelling and downwelling, while larvae of other taxa were transported onshore during downwelling and offshore during upwelling.

Photo by Dr. Richard Emlet, Oregon Institute of Marine Biology, University of Oregon

\section{INTRODUCTION}

Many coastal invertebrates and fish have complex life cycles in which larvae develop in water over the continental shelf. During this period larval mortality is generally high (Rumrill 1990), and a potentially important source of mortality is the transport of larvae away from settlement sites, so that at the end of development, suitable habitat is unavailable, e.g. 'larval wastage' (Thorson 1950). 
Variations in the supply of settling larvae can have a major impact on the structure and dynamics of nearshore communities (Underwood 1981, Underwood \& Denley 1984, Gaines et al. 1985, Menge 1991, Underwood \& Chapman 1996) and can play an overriding role in controlling population dynamics within a species (Gaines \& Bertness 1994). Hence, the causes of variations in larval supply have become the focus of much marine ecological research. Numerous papers have been published on this subject addressing socalled 'supply-side ecology' or 'bottom-up effects' of larval supply (Connell 1985, Underwood \& Fairweather 1988, Menge et al. 1997, Menge 2000). The growing understanding of the importance of larval supply to the ecology of coastal communities has prompted benthic ecologists to focus on the causes of variation in larval supply. Researchers have attempted to relate larval supply to coastal oceanography, with variations in larval supply controlled by larval wastage. Wind-driven coastal upwelling and downwelling events have been a particular focus of this research. Researchers believe that during upwelling offshore flow in the surface layer (the Ekman layer) carries larvae so far from shore that they cannot return to settle, resulting in high larval wastage (Alexander \& Roughgarden 1996, Connolly \& Roughgarden 1999, Connolly et al. 2001). Researchers have argued that in areas of persistent upwelling, community processes and structure in the intertidal zone reflect the consequences of low larval settlement (Roughgarden et al. 1988, Alexander \& Roughgarden 1996, Connolly \& Roughgarden 1999, Broitman et al. 2001, Connolly et al. 2001). In wind-driven downwelling the reverse occurs: larvae in the surface layer are carried to shore, leading to high settlement (Farrell et al. 1991). In this dispersal scenario, larvae behave as passive particles carried along with the flow. Given that swimming speeds of many larval types (generally $\mathrm{mm} / \mathrm{s}$ ) are much slower than flow rates in the Ekman layer (generally $\mathrm{cm} / \mathrm{s}$ ) (Barber \& Smith 1981, Chia et al. 1984), this is not an unreasonable assumption.

This hypothesis is intuitively appealing, but few studies have actually tested it. Roughgarden et al. (1988) reported that under the influence of coastal upwelling, larvae of an intertidal barnacle were carried offshore, that the amount of offshore transport varied with the strength of upwelling, and that variations in upwelling were correlated with variations in settlement at the shore. In contrast, Poulin et al. (2002) in a study in Chile found that larvae of an intertidal gastropod remained close to shore despite upwelling. The hypothesis that upwelling and downwelling currents affect larval dispersal has had a large influence on the thinking of marine ecologists, yet surprisingly little effort has gone into testing this hypothesis.

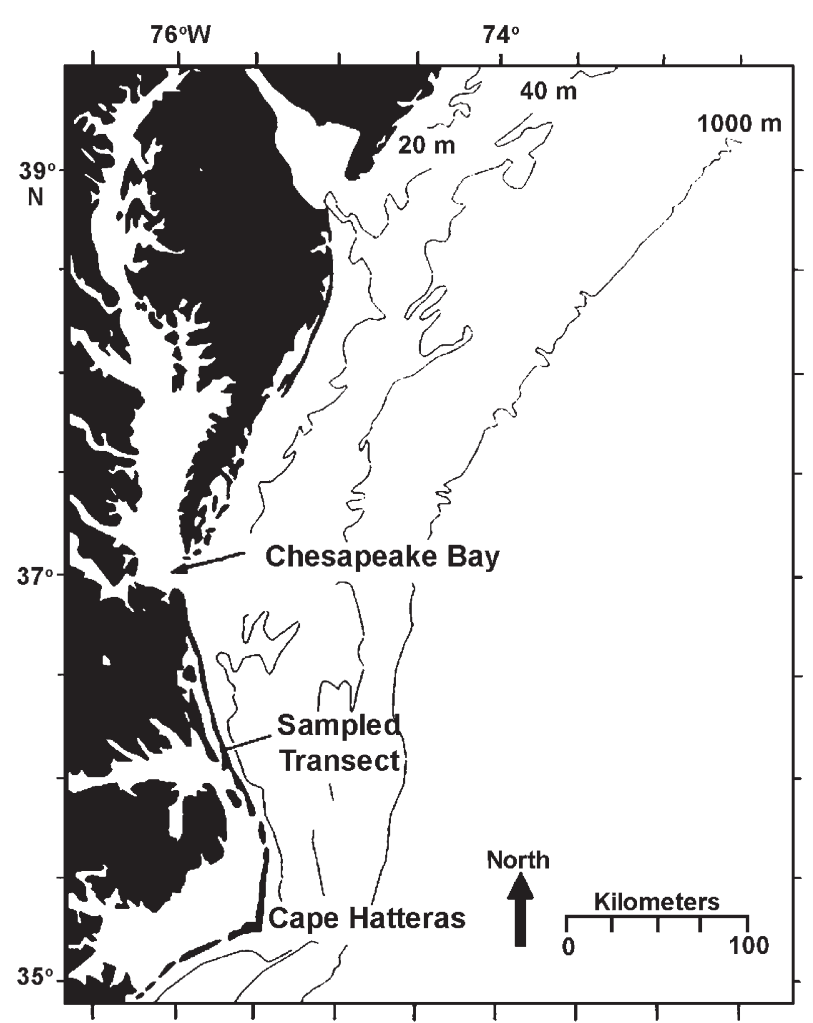

Fig. 1. Map of study area off Duck, North Carolina, USA. Redrawn from Garland et al. (2002)

We tested the hypothesis that larvae are swept offshore during upwelling and shoreward during downwelling. We sampled bivalve larvae, slow-swimming ciliated larvae that should be particularly susceptible to transport by wind-driven currents. Samples and oceanographic data were collected off Duck, North Carolina along a transect perpendicular to shore over 1 wk during which currents shifted from upwelling to downwelling and then back to upwelling. Results demonstrate that cross-shelf transport is dependent on the vertical distribution of larvae in the water column and their behavior. Larvae of some species of bivalves actually remained close to shore despite upwelling and downwelling.

\section{MATERIALS AND METHODS}

The fieldwork for this study took place between 21 and 27 August 1994. On 5 d during this period we sampled a transect centered on the Army Corps of Engineers Field Research Facility (FRF) at Duck, North Carolina, USA (Fig. 1). The coast to the north and south of the transect is characterized by relatively simple submarine and coastal topography. It was hoped that this would minimize topographically induced along- 
shore variations in the oceanography. The transect was oriented perpendicular to the coast and extended $20 \mathrm{~km}$ offshore. Samples were collected at 4 or 6 stations (1, 2, 4, 9, 14 and $19 \mathrm{~km}$ offshore); the 1 and $19 \mathrm{~km}$ stations were not sampled on 23 August due to rough seas (see Table 1).

At each station, a SeaBird 911 ConductivityTemperature-Depth (CTD) cast was made. Simultaneous with the CTD cast, an Acoustic Doppler Current Profiler (ADCP) was used to measure the vertical profile of currents. The currents were measured with an RDI 1.2 MHz narrow-band instrument mounted on a catamaran that held the transducer at a depth of $0.4 \mathrm{~m}$. Velocity profiles were made with a vertical resolution of $1 \mathrm{~m}$ and recorded at 1 to $2 \mathrm{~Hz}$ while the ship held position for the CTD cast. A detailed description of the collection and processing of the physical oceanographic data can be found in Waldorf et al. (1995).

Plankton samples were collected with a centrifugal pumping system. A $5 \mathrm{~cm}$ diameter hose was connected to the CTD rosette and a deck-mounted pump. Output from the CTD provided information on the depth from which each sample was collected. Water from the pump was passed through a $100 \mu \mathrm{m}$ mesh net suspended in a large tub of water. The pumping rate was $2271 \mathrm{~min}^{-1}$, and $680 \mathrm{l}$ were sampled at each depth. Sampling depths were selected based upon the water depth. At the shallowest stations (1 $\mathrm{km}$ from shore and $<10 \mathrm{~m}$ depth) samples were collected a couple of meters above the bottom and below the surface (Table 1). At stations $2 \mathrm{~km}$ from shore 3 or 4 depths were samples (Table 1). At all other stations, 3 to 5 depths were sampled (Table 1). Whenever possible,

Table 1. Biological sampling locations (distance offshore and depth). Sampling was reduced on 23 August due to rough seas

\begin{tabular}{|c|c|c|c|}
\hline Date & $\begin{array}{l}\text { Distance } \\
\text { offshore, km } \\
\text { (depth, m) }\end{array}$ & Date & $\begin{array}{l}\text { Distance } \\
\text { offshore, km } \\
\text { (depth, m) }\end{array}$ \\
\hline $21 \mathrm{Aug}$ & $\begin{array}{l}1(2,7) \\
2(2,8,13) \\
4(2,5,8,13,17) \\
9(2,5,8,14,19) \\
14(2,6,9,16,23) \\
19(2,7,12,18,23)\end{array}$ & $25 \mathrm{Aug}$ & $\begin{array}{l}2(2,8,13) \\
4(2,8,17) \\
9(2,10,18) \\
14(2,9,15,19,22) \\
19(2,7,12,18,24)\end{array}$ \\
\hline $23 \mathrm{Aug}$ & $\begin{array}{l}2(2,9,14) \\
4(3,11,17) \\
9(7,12,15,18) \\
14(3,8,13,18,23)\end{array}$ & 27 Aug & $\begin{array}{l}1(3,7) \\
2(2,5,9,12) \\
4(2,8,13,17) \\
9(2,6,10,14,18) \\
14(2,7,12,18,25) \\
19(2,7,12,18,24)\end{array}$ \\
\hline 24 Aug & $\begin{array}{l}1(3,7) \\
2(3,8,13) \\
5(3,7,12,17) \\
9(3,8,14,20) \\
14(7,11,17,24) \\
19(3,8,13,19,24)\end{array}$ & & \\
\hline
\end{tabular}

samples were collected within the mixed layer, in the thermocline, and between the thermocline and the bottom. Samples were preserved in buffered formalin.

In the laboratory, each sample was washed free of formalin on a $53 \mu \mathrm{m}$ sieve, transferred to a $250 \mathrm{ml}$ beaker, and, with the aid of an electronic balance, made up to $200 \mathrm{ml}$ (200 g). The sample was homogenized by vigorous haphazard stirring, and a $12 \mathrm{ml}$ subsample was removed with a Stempel pipette (Peterson et al. 1979, Omori \& Ikeda 1984). Multiple $12 \mathrm{ml}$ subsamples were counted until at least 100 individuals of the most common organisms were enumerated. This yielded a sample standard deviation of ca. $10 \%$ for the most abundant organisms (including the subjects of this study) and between 10 and $20 \%$ for the less common species (Venrick 1978). To test the subsampling technique, we compared the number of organisms in 4 samples by subsampling and by counting the entire sample. No statistically significant differences (MannWhitney $U$-test, $\mathrm{p}>0.05$ ) were found between the concentrations of organisms determined by the 2 methods, indicating that the subsampling technique adequately described the samples.

The plankton samples were sorted under a dissecting microscope equipped with polarizing filters. The filters were placed between the sample and the light source, and between the sample and the microscope lens. The filters were rotated until the shells of bivalves and gastropods appeared to 'glow' due to the birefringence caused by the crystalline structure of the shell (Gallager et al. 1989). Lighting the samples in this way greatly facilitated sorting. Bivalve larvae were identified to genus and, when possible, to species using various identification guides (Thorson 1946, Sullivan 1948, Rees 1950, Loosanoff et al. 1966, Chanley \& Andrews 1971).

During the processing of the physical oceanographic data, current velocities were decomposed into alongshore and cross-shore components. Alongshore was defined as $20^{\circ} \mathrm{W}$ of true north. Contour plots of the distribution of the biological and physical data were made using the Noesys Transform contour plotting program with the Kriging option for gridding and interpolating. In these plots, the position of contours close to shore (within $5 \mathrm{~km})$, because of the short distance between stations, are accurately depicted. As station spacing increased with distance offshore, the degree of confidence with which we viewed the position of contours decreased.

If larvae are acting as passive particles, then they should follow a water mass as it is displaced and the concentration of the larvae should be correlated to the physical parameters defining the water mass. If the larvae are not acting as passive particles, then significant correlations with the physical parameters should not be present. Spearman's Rank correlations between the concentration of the larval taxa and distance from shore, 

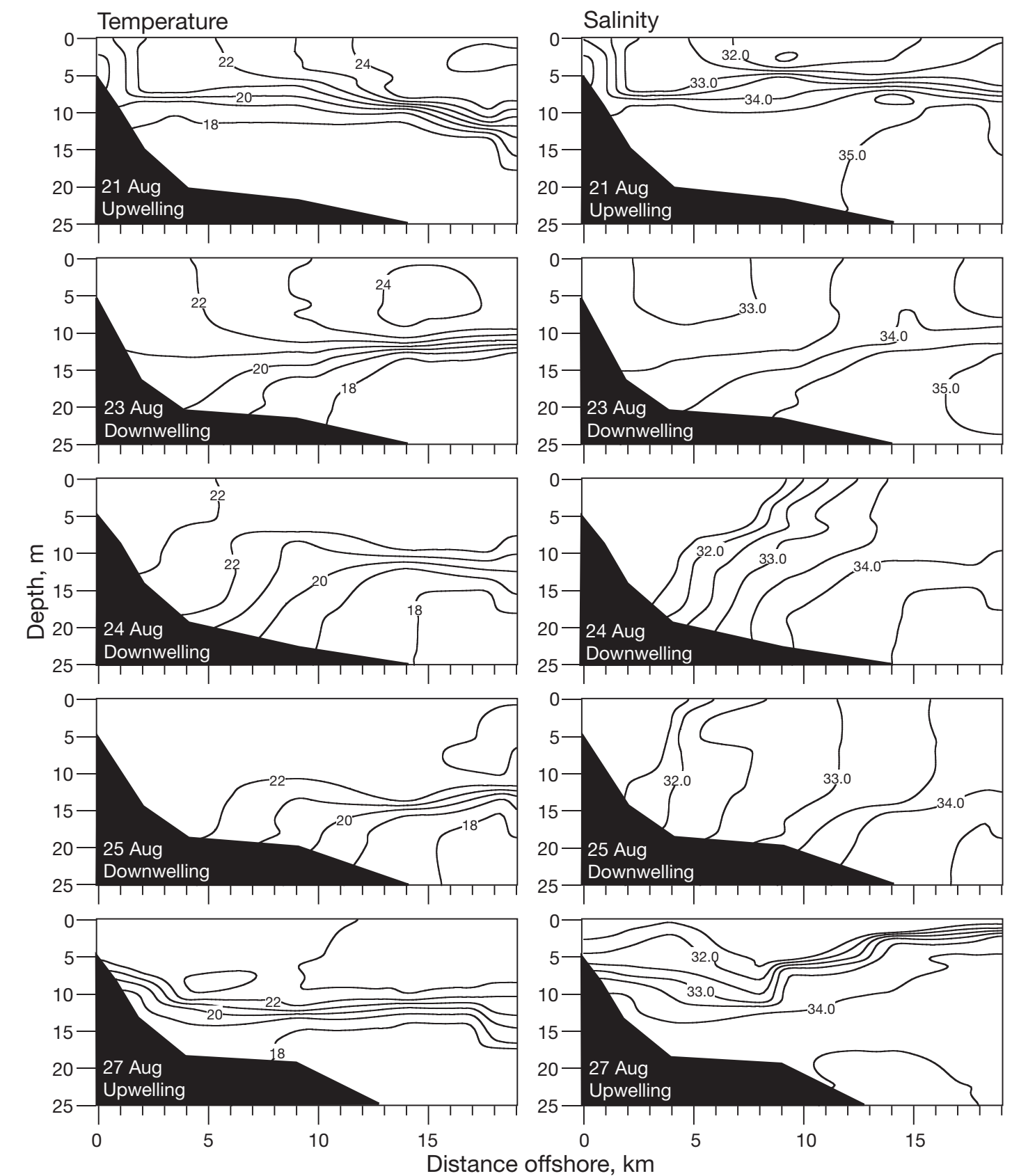

Fig. 2. Contour plots of temperature (left-hand column) and salinity (right-hand column) on transect off Duck, North Carolina, USA. Upwelling conditions prevailed on 21 and 27 August and downwelling prevailed on 23, 24, and 25 August

depth, temperature, salinity, and density tested this hypothesis. Significance levels were modified following the Bonferroni correction for multiple correlations.

\section{RESULTS}

On 21 August, the first sampling date, upwelling conditions prevailed. Southwest winds had been blowing for 2 d prior to sampling (Waldorf et al. 1995).
Beyond $\sim 5 \mathrm{~km}$ from shore a strong thermocline was present (Fig. 2). Within $5 \mathrm{~km}$ of shore, upwelling currents had drawn the thermocline upward such that water with characteristics of the top of the thermocline (salinity 32.4 to 34 , temperature 23.5 to $20.5^{\circ} \mathrm{C}$ ) contacted the surface. Surface currents $(<5 \mathrm{~m}$ depth) were offshore during this period and ranged from 10 to $30 \mathrm{~cm} \mathrm{~s}^{-1}$ (Waldorf et al. 1995, Cudaback \& Largier 2001). On the next 3 sample dates $(23,24$, and 25 August) strong winds blew from the northeast causing 
surface waters to move shoreward and downwell at the coast. The thermocline was bent downward until it contacted the bottom, and the bottom contact point moved steadily offshore over the period (Fig. 2). The $20^{\circ} \mathrm{C}$ isotherm was located about in the middle of the thermocline. On 23 August this isotherm contacted the bottom at about $4 \mathrm{~km}$ from shore, on 24 August the contact point had moved offshore to about $7 \mathrm{~km}$, and by 25 August it was $9 \mathrm{~km}$ offshore. Surface currents were onshore during downwelling days with flows ranging from 5 to $20 \mathrm{~cm} \mathrm{~s}^{-1}$ (Waldorf et al. 1995, Cudaback \& Largier 2001). On 24 and 25 August, very low-salinity water $(<31)$ was present within $5 \mathrm{~km}$ of shore (Fig. 2). This was an intrusion of Chesapeake Bay estuarine plume water; the intruding plume of water is characteristic of downwelling events at this location (Rennie et al. 1999, Cudaback \& Largier 2001). On 26 August, winds shifted to the southwest (upwelling favorable), and by 27 August (the last sampling date) upwelling was established. Under these conditions, plume water rose to the surface forming a lens of low-salinity water that was transported offshore. Upwelling surface currents were between 5 and $20 \mathrm{~cm} \mathrm{~s}^{-1}$ (Waldorf et al. 1995, Cudaback \& Largier 2001). The thermocline, which on 25 August was contacting the bottom between 5 and $10 \mathrm{~km}$ offshore, was drawn shoreward and upward such that the top of the thermocline $\left(22^{\circ} \mathrm{C}\right)$ was approaching the surface. During the week, as conditions shifted from upwelling to downwelling and back to upwelling, the waters within $5 \mathrm{~km}$ of shore were repeatedly exchanged with offshore waters from above (during downwelling) or below (during upwelling) the thermocline.

Given the extensive exchanges of water masses in the nearshore, the speed of the cross-shelf currents, and the slow bivalve larval swimming speeds, the hypothesis predicts that larvae will behave as passive particles in a flow and that during shifts from upwelling to downwelling they will be swept first seaward and then landward. The detailed zooplankton sampling allows a careful test of these predictions.

During the week most of the taxa enumerated displayed large day-to-day variations in abundance, with one or more days with very low abundances. Four bivalve taxa (Spisula solidissima, Ensis directus, Tellina spp., and Mulinia lateralis) were consistently abundant throughout the week and will be the focus of the analysis.

The distributions of larval Spisula solidissima and Ensis directus were significantly positively correlated with depth, salinity, and density and negatively correlated with temperature (Table 2), suggesting that the larvae tended to be found below the thermocline. This can be clearly seen in Fig. 3, where larval concentrations are plotted with isotherms (a clear indicator of upwelling and downwelling conditions). On 21 August, a day of upwelling, these larvae were distributed below the thermocline and across the shelf with a small concentration adjacent to shore where the thermocline was bent upward by upwelling. On 23 August downwelling conditions prevailed; these larvae were still found below the thermocline, but the most inshore edge of their distribution was about $5 \mathrm{~km}$ offshore where, due to downwelling, the $20^{\circ} \mathrm{C}$ isotherm (near the middle of the thermocline) was bent downward and contacted the bottom. Downwelling continued on 24 and 25 August, and the larval distributions remained essentially unchanged from 23 August. Upwelling occurred on 27 August, and we saw larval distributions similar to those observed on 25 August; larvae were found below the thermocline, they were abundant across the shelf, and a concentration of larvae was present next to the coast where upwelling had bent the thermocline upward.

The larvae of Tellina spp. and Mulinia lateralis displayed a very different pattern of cross-shelf distribution. Their abundances were significantly negatively correlated only to distance from shore (Table 2), indicating that they tended to remain close to shore throughout the week. During upwelling on 21 August, they were found within $5 \mathrm{~km}$ of shore and above $15 \mathrm{~m}$ depth (Fig. 4) in the upwelling water. On 23 August, the first day of downwelling, there were 2 centers of high larval abundance, one located within $5 \mathrm{~km}$ of shore at depths $<15 \mathrm{~m}$ and the other about $9 \mathrm{~km}$ offshore below the thermocline at ca. $15 \mathrm{~m}$ depth. The distributions on 24 and 25 August, downwelling days, were similar; larvae were found within $7 \mathrm{~km}$ of shore and at depths $<10 \mathrm{~m}$. Between 25 and 27 August, upwelling commenced and the waters within ca. $5 \mathrm{~km}$ of shore were nearly completely replaced by upwelled waters (Fig. 2). On 27 August, larvae were found within $4 \mathrm{~km}$ of shore and above $7 \mathrm{~m}$ depth. 


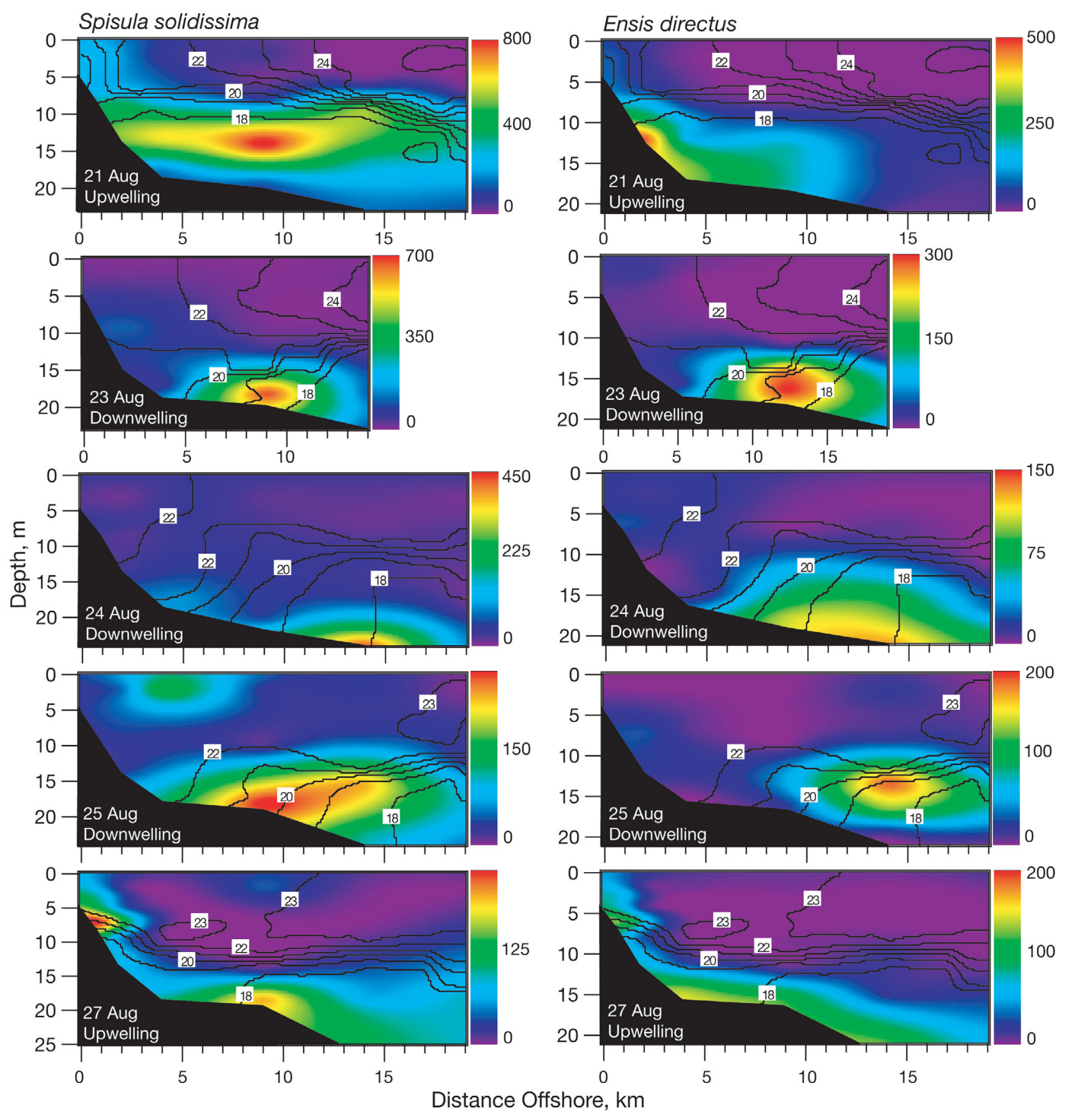

Fig. 3. Spisula solidissima and Ensis directus. Contour plots of bivalve larval concentrations (no. $\mathrm{m}^{-3}$, concentration scale to right of each panel) plotted with lines of constant temperature. Data were collected over 1-wk period when conditions shifted from upwelling (21 August) to downwelling (23, 24, and 25 August) and back to upwelling (27 August). Left-hand column: S. solidissima; right-hand column: E. directus

\section{DISCUSSION}

During the week of sampling, alongshore flow was to the north during upwelling and to the south during downwelling (Waldorf et al. 1995, Cudaback \& Largier 2001). These alongshore currents were fast enough ( $\mathrm{cm}$ to tens of $\mathrm{cm} \mathrm{s}^{-1}$ ) to move waters kilometers in a day. To test the hypothesis that larval distributions were affected by upwelling and downwelling, we must look at the cross-shelf distribution of the larvae relative to the oceanography, but this analysis can be confounded by variations in abundance of larvae in the alongshore direction; discrete clouds of larvae distributed in the alongshore direction 'blown' past the sample transect may appear as variations in the cross-shelf distribution. 


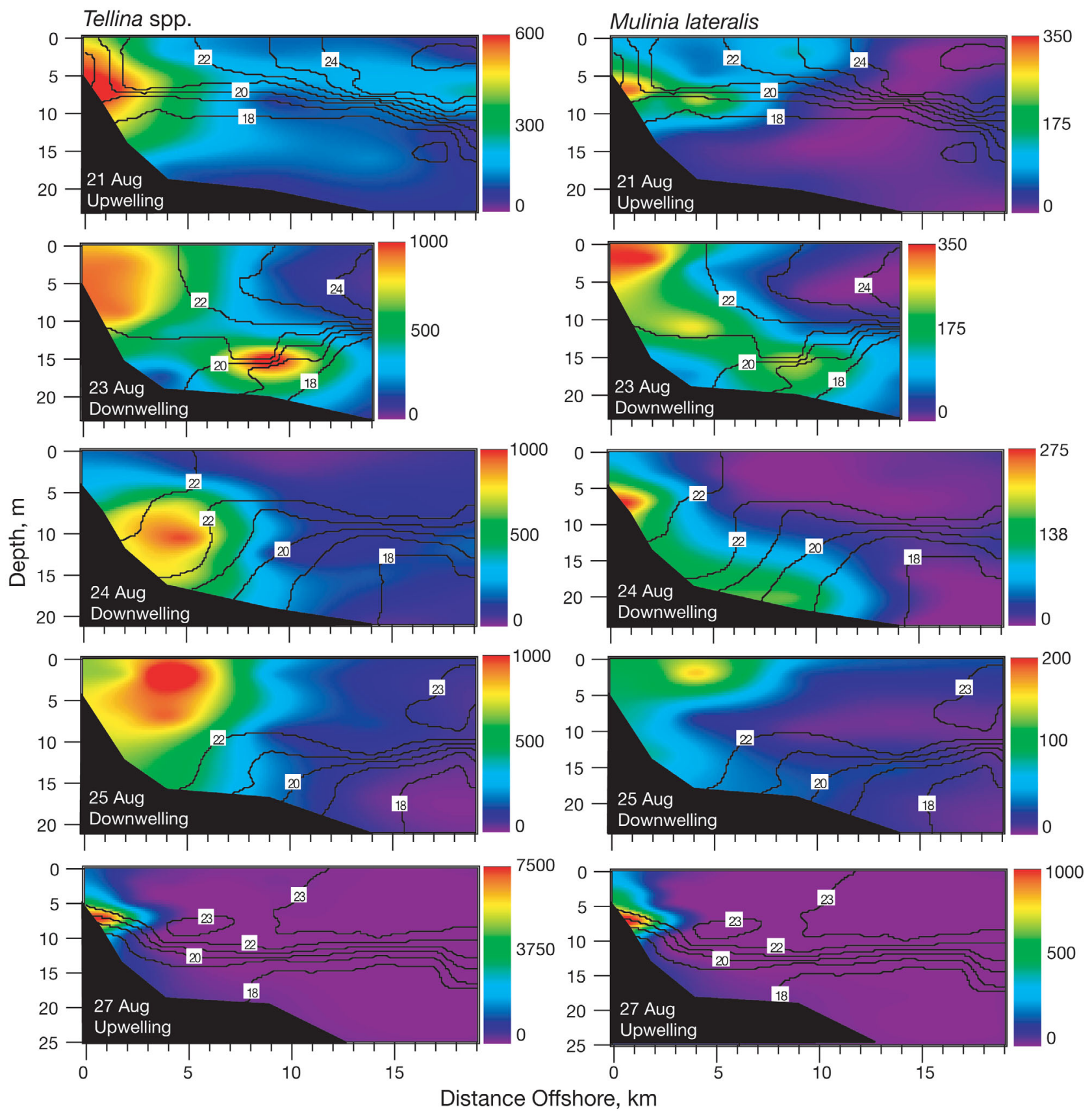

Fig. 4. Tellina spp. and Mulinia lateralis. Contour plots of bivalve larval concentrations (no. $\mathrm{m}^{-3}$, concentration scale to right of each panel) plotted with lines of constant temperature. Data were collected over a 1-wk period when conditions shifted from upwelling (21 August) to downwelling $(23,24$, and 25 August) and back to upwelling (27 August). Left-hand column: Tellina spp.; right-hand column: M. lateralis

In 2 earlier papers, we presented data sampled from a grid of stations during a downwelling (Shanks et al. 2002) and upwelling (Shanks et al. 2003) event. The grid consisted of 5 transect lines with stations extending $20 \mathrm{~km}$ offshore and $30 \mathrm{~km}$ alongshore. The data presented in this current paper were collected at the central transect line of this grid. The 24 August data, a day of downwelling, were collected during the sam- pling of the grid of transects. Along the central transect line, the larval distributions of the 4 bivalve taxa discussed in this current paper as well as most of the other taxa enumerated were the same as those seen at transect lines to the north and south (Shanks et al. 2002); the distributions of larvae were consistent in the alongshore direction. The data presented in Shanks et al. (2003) were collected earlier in August during an 
upwelling event, and here again we observed that the distributions of larvae in the cross-shelf direction were consistent across the grid of 5 transects. From these 2 papers we concluded that the cross-shelf distributions of many taxa of larvae, including those discussed in this current paper, were consistent in the alongshore direction. The abundances of the 4 taxa discussed in the present paper were consistent through the week of sampling and their cross-shelf distributions, as demonstrated by the previous studies (Shanks et al. 2002, 2003), were also consistent in the alongshore direction. For these 4 taxa, it is unlikely that variations in the cross-shelf distributions were due to variations in alongshore abundances.

During the week of sampling, conditions shifted from upwelling (21 August) to downwelling $(23,24$, and 25 August) and then back to upwelling (27 August). As conditions shifted from one oceanographic regime to another, the waters within ca. $5 \mathrm{~km}$ of shore were nearly completely exchanged with offshore waters. Cross-shelf current speeds ranged from several $\mathrm{cm} \mathrm{s}^{-1}$ to several tens of $\mathrm{cm} \mathrm{s}^{-1}$ (Waldorf et al. 1995, Cudaback \& Largier 2001); cross-shelf current speeds, therefore, were 1 to 2 orders of magnitude faster than the swimming speeds of bivalve larvae $\left(\leq 0.1 \mathrm{~cm} \mathrm{~s}^{-1}\right)$. Because the cross-shelf currents were so much faster than larval swimming speeds, the hypothesis predicts (Roughgarden et al. 1988) that bivalve larvae should behave as passive particles, during upwelling they should be transported offshore by Ekman transport, and during downwelling they should be transported back onshore.

Larval Spisula solidissima and Ensis directus were found below the thermocline. During downwelling, the thermocline was bent downward until it contacted the bottom at 5 or more $\mathrm{km}$ offshore. The waters landward of this contact point were composed of waters from above the thermocline and Chesapeake Bay plume water. During downwelling, these larvae were found below the thermocline and at distances $>5 \mathrm{~km}$ from shore. During upwelling, the waters within ca. $5 \mathrm{~km}$ of shore were moved offshore, drawing the thermocline toward the surface. S. solidissima and E. directus larvae continued to remain below the thermocline and were transported landward during upwelling. Through the week of sampling, as conditions changed from upwelling to downwelling and back to upwelling, larval $S$. solidissima and $E$. directus acted like passive particles, as the hypothesis predicts, and were swept back and forth across the shelf; however, their closest approach to shore occurred during upwelling, which is in opposition to that predicted.

In August, larval settlement to the nearshore adult population of Spisula solidissima (i.e. adults within $5 \mathrm{~km}$ of shore) probably occurred during upwelling as subthermocline waters with their entrained larvae were pulled shoreward. Ma (2001) studied the distribution and settlement of $S$. solidissima larvae at a more northerly site (still in the Mid-Atlantic Bight) and earlier in summer (July). He found larvae distributed above the thermocline and, at this time of year, water temperature above the thermocline were similar to those found below the thermocline in our August measurements; larvae of this species may have a preferred temperature range as has been observed in laboratory behavior studies of other bivalves (Hidu \& Haskin 1978, Mann \& Wolf 1983). In Ma's work, nearshore settlement of $S$. solidissima larvae occurred during downwelling events when water from above the thermocline was pulled downward and contacted the bottom. This observation suggests that larvae were, as the hypothesis predicts, transported shoreward by downwelling and seaward by upwelling. Consistent with the hypothesis, S. solidissima larvae appear to behave like passive particles in flow, but, depending on their position in the water column, their cross-shelf transport is either consistent with the hypothesislarvae above the thermocline are swept offshore in upwelling and shoreward in downwelling - or exactly opposite when larvae are found below the thermocline. One cannot predict the effect upwelling and downwelling will have on the distribution of larvae without knowing the vertical distribution of the larvae in the water column.

Despite extensive water mass exchange (Fig. 2) and cross-shelf currents 10 to 100 times faster than larval swimming speeds, most larval Tellina spp. and Mulinia lateralis remained within $5 \mathrm{~km}$ of shore. This was true in the present study as well as in the data reported in Shanks et al. $(2002,2003)$. The distributions of these larvae do not fit the hypothesis; they clearly did not act like passive particles in the cross-shelf flow, upwelling did not carry them offshore, and downwelling did not carry them onshore-they remained in the nearshore waters. The following model suggests how slowly swimming ciliated larvae may accomplish this feat.

During downwelling, flow is shoreward at the surface, downwells near shore, and flows seaward at depth$_{i}$ in essence, downwelling generates a convergence near the shore. At convergences associated with oceanographic fronts, models and observations demonstrate that zooplankton, which maintain a preferred depth and swim upward against the downwelling flow, can become trapped in the flow field and concentrated (Franks 1992, 1997). At the nearshore convergence generated by downwelling, larvae that maintain a preferred depth, like organisms at a convergent front, may become trapped by the flow field and concentrated (Fig. 5). During upwelling, flow is offshore at the surface, upwells near shore, and flows 

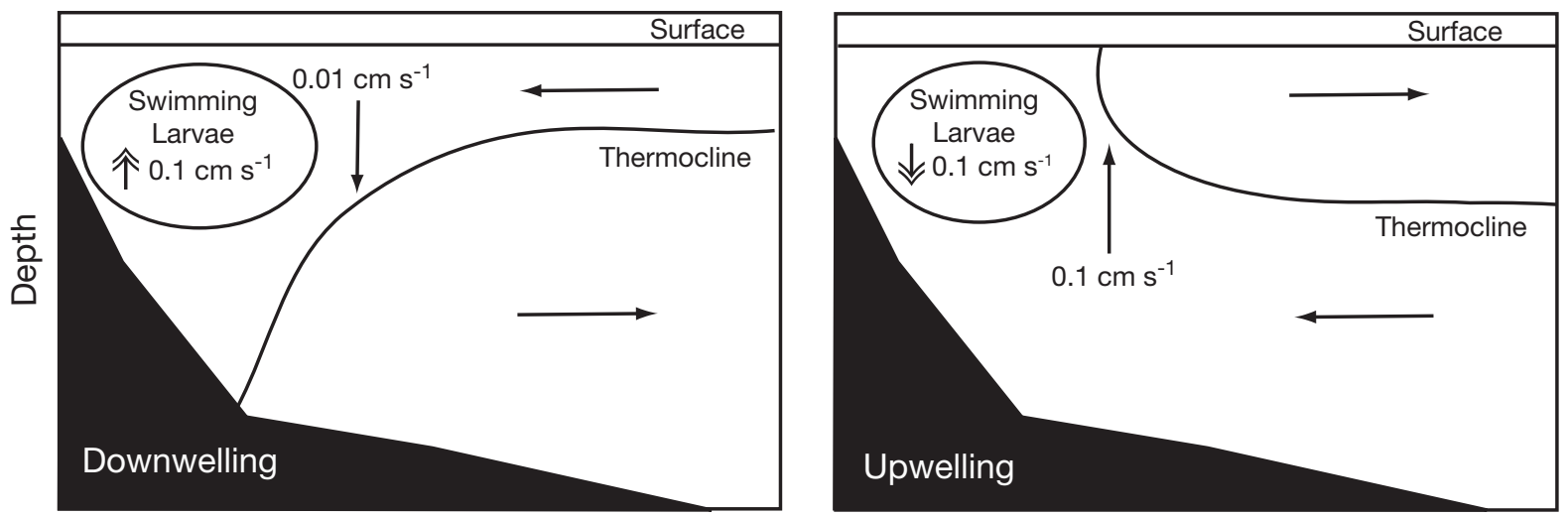

\section{Distance Offshore}

Fig. 5. Schematic of possible behaviors of larvae retained nearshore during upwelling and downwelling. Larvae may be retained near coast during downwelling (convergent flow against coast) if they try to maintain preferred depth in face of converging and downwelling flow. Conversely, larvae may be retained during upwelling (divergent flow at the coast) if they try to maintain a preferred depth in face of upwelling flow. For this to work, larvae must respond to pressure changes, swimming up on pressure drop and down on pressure rise, and must swim as fast or faster than vertical current speeds

shoreward at depth; the flow field can be viewed as a divergence near the shore. In such a flow field, larvae that maintain a preferred depth may swim downward against the rising current and may become trapped and concentrated by the flow field (Fig. 5) (Olsen \& Backus 1985, Lennert-Cody \& Franks 1999). In upwelling or downwelling, larvae that maintain a preferred depth by swimming against vertical currents may become trapped near the coast by the flow fields.

If larvae attempting to maintain a preferred depth in the face of upwelling or downwelling currents fail to swim against the vertical currents, they will be swept toward the surface (upwelling) or bottom (downwelling) and into currents flowing offshore. As they are transported away from the coast the vertical currents will decrease to near zero and larvae can return to their preferred depth. Larvae swimming down from the surface during an upwelling event may enter the onshore flow associated with upwelling and be carried back toward the coast. The reverse may happen when larvae swim up from the bottom during downwelling. In either case, larvae swept out of the nearshore, by returning to their preferred depth, may be carried back toward the coast. Like a countercurrent exchange system, this would lead to the concentration of larvae near the coast.

For trapping to occur, larvae must swim against the vertical current. This could be accomplished by swimming up on a pressure drop and down on a pressure increase, behaviors that have been observed in laboratory studies of bivalve larvae (Cragg 1980, Mann et al. 1991). In addition, larvae must swim at least as fast as vertical current speeds. Bivalve larval swimming speeds are around $0.1 \mathrm{~cm} \mathrm{~s}^{-1}$ (Chia et al. 1984) and vertical currents during downwelling and upwelling off Duck were on the order of 0.01 and $0.1 \mathrm{~cm} \mathrm{~s}^{-1}$, respec- tively (Shanks et al. 2002, 2003); larval swimming speeds appear to be at least as fast as the vertical current speeds. This model suggests that simple behaviors, those within the capacity of larval bivalves, may allow larvae to remain next to the coast despite upwelling and downwelling.

In a recent paper (Genin et al. 2005), the vertical displacement of individual zooplankters and vertical currents was measured simultaneously. Zooplankters were found to remain at a depth by swimming against upwelling and downwelling currents but were carried along passively with horizontal flow. Modeling of the behavior and flow field suggested that the combination would lead to concentrations of zooplankton during both upwelling and downwelling events, and subsequent field sampling confirmed the predictions of the model (Genin et al. 2005). These observations are consistent with our model, which explains how slowswimming larvae might remain near the coast during upwelling and downwelling.

We conclude, as did Shanks et al. $(2002,2003)$, that larvae, even very slow-swimming larvae, are not necessarily at the mercy of the currents. They can remain close to shore despite upwelling and downwelling. This conclusion is quite different from that reached by Roughgarden et al. (1988), who concluded that barnacle larvae were swept offshore by upwelling and remained closer to shore during downwelling. This difference could be due to the organisms studied, barnacles vs. several species of bivalves. Surprisingly, we do not know the vertical distribution of larval barnacles except for some species that reside in estuaries (Bousfield 1955, de Wolf 1974). Perhaps Balanus glandula larvae, the focus of the Roughgarden et al. paper, are distributed above the thermocline, in which case they 
would be swept offshore by upwelling and onshore by downwelling. Cross-shelf currents during upwelling and downwelling change with depth. Hence, to understand how cross-shelf currents affect larval transport, we obviously need to know the depth distribution of the larvae and how this changes during their ontogeny.

Alternatively, the difference between the studies may be one of sample design. Roughgarden et al. used samples collected by the California Cooperative Fisheries Investigation (CalCOFI). CalCOFI sampling was designed to investigate the biology of anchovy and sardine, fishes generally found over the continental shelf, and because of this aim, samples were not collected particularly close to shore. In the Roughgarden et al. study, samples were collected no closer than $9 \mathrm{~km}$ from shore. In the present study and in Shanks et al. (2002, 2003), larvae unaffected by upwelling and downwelling were observed to maintain a distribution within $\sim 5 \mathrm{~km}$ of the coast. It is quite possible that barnacle larvae, like some taxa of bivalve larvae, are not swept offshore by upwelling, but, due to their behavior coupled with the physical oceanography, the bulk of the population remains close to the coast. The CalCOFI samples used by Roughgarden et al. would have missed this phenomenon entirely. With no sampling between $9 \mathrm{~km}$ and the shore, Roughgarden et al., in fact, could not test the hypothesis that upwelling sweeps larvae offshore and downwelling carries them back again.

One might argue that the waters off Duck, North Carolina and the Mid-Atlantic Bight in general are areas of weak upwelling while the west coast of North America is characterized by strong seasonal upwelling. Perhaps the difference between the 2 studies is due to this difference in upwelling regimes. Poulin et al. (2002), however, found that along the Chilean coast, an area of strong persistent upwelling, competent larvae of the gastropod Concholepas concholepas were not transported offshore by upwelling. In our study, waters within ca. $5 \mathrm{~km}$ of shore were nearly completely exchanged with offshore water during each shift in oceanographic regime. During this type of water mass exchange, truly passive particles (e.g. dye) are washed offshore (Csanady 1972a,b, 1974). Larval bivalves did not act like a dye tracer; instead they remained close to shore despite the exchange of water masses. While upwelling is less persistent in the Central Atlantic Bight than off California, the offshore surface currents generated by Ekman transport are comparable in speed in both places and much faster than the swimming speed of most larvae; in both locations the offshore flow is 1 to 2 orders of magnitude faster than the swimming speeds of small larval invertebrates, and hence the larval bivalves we sampled, if the hypothesis was supported, should have been swept offshore by upwelling.
On the west coast of North America, the upwelling season commences in the spring when the direction of the coastal winds shifts seasonally. As the upwelling season progresses, the California Current is increasingly perturbed and large offshore jets (or squirts) of water and eddies form offshore of the large capes and headlands (Strub \& James 2000). Researchers have speculated that these headland jets transport larvae of coastal species far out to sea and away from settlement sites at the shore, that alongshore variation in the distribution of jets and, hence, offshore larval transport leads to variation in settlement at the coast, and that the alongshore variation in larval settlement results in alongshore variation in community structure (Roughgarden et al. 1988, Alexander \& Roughgarden 1996, Connolly \& Roughgarden 1999, Connolly et al. 2001). This train of reasoning is dependent on the first stepare larvae of coastal species transported offshore by jets? Research has demonstrated that headland jets transport the larvae of continental shelf fishes offshore (Fiedler 1986, Haury et al. 1986), but we can find no similar studies that have tested the hypothesis that the larvae of nearshore or intertidal species are transported offshore by jets. There are correlative studies that have related the distribution of headland jets to the distribution of settlement and recruitment (Ebert \& Russell 1988, Alexander \& Roughgarden 1996, Connolly et al. 2001), but a correlation suggests a hypothesis to be tested, not cause and effect.

Among the ways physical oceanographers have studied the jets is by following the path of current drifters released over the continental shelf. Most drifters have been released tens of kilometers from shore, and these drifters are rapidly swept offshore by the jets and become entrained in the eddies (Barth \& Smith 1998, Barth et al. 2000). The few drifters that have been released nearer the coast and landward of the upwelling front, however, have not been caught up by the jets and swept offshore; rather they have drifted back toward the coast (Barth \& Smith 1998, Barth et al. 2000). In addition, modeling and measurements suggest that cross-shelf movement of water decreases as the coast is approached (Austin \& Barth 2002, Austin \& Lentz 2002, Largier 2003). These observations suggest that larvae of coastal organisms that remain close to shore may not experience offshore displacement by the headland jets and eddies. The hypothesis that larvae of coastal organisms are swept offshore in headland jets and eddies obviously needs testing.

If slow-swimming larvae, bivalve larvae, can remain near the coast despite upwelling and downwelling, then essentially all types of larvae have this potential. In fact, some dinoflagellates swim so fast (Kamykowski et al. 1992) that they may at times have this potential as well. If all larvae have this potential, then it makes 
more sense, from an evolutionary perspective, that the larvae of coastal species remain near the coast and future settlement sites rather than allowing themselves to be swept offshore. In fact, in the California Current system, larvae of nearshore fishes and benthic crustaceans (e.g. adult depth distribution $<30 \mathrm{~m}$ ) tend to be abundant in very nearshore waters (e.g. within $3 \mathrm{~km}$ of shore) and rare in offshore waters (e.g. $>20 \mathrm{~km}$ from shore), while larvae of continental shelf and slope species tend to be found far from shore and not close to shore (Shanks \& Eckert 2005).

We tested the hypothesis that larvae are swept offshore by upwelling and onshore by downwelling. For the same species, the hypothesis at times successfully explains larval distribution and transport (Ma's observations of Spisula solidissima in July) (Ma 2001), while at other times it does not (our observations of the same species in August). For species such as S. solidissima, the hypothesis successfully explains their distribution when they are found in the surface water above the thermocline, but if they are distributed below the thermocline, then upwelling will carry them onshore. Obviously, to understand how upwelling and downwelling affect larval transport, one must know the vertical distribution of the larvae. For some types of larvae, e.g. slow-swimming ciliated larvae, the hypothesis was rejected; they were not swept offshore during upwelling, nor were they swept onshore by downwelling. The proposed behavior model suggests that slow swimming coupled with a simple depth-keeping behavior may maintain larvae close to a coast despite upwelling and downwelling. Given the very slow swimming speed of bivalve larvae, we conclude that there is no reason to expect that any type of meroplankter is swept offshore by upwelling. The effect of upwelling and downwelling on larval distributions varies with species. Without careful field sampling during upwelling and downwelling, one cannot invoke offshore transport by upwelling as an explanation for patterns of larval settlement.

Acknowledgements. Field assistance was provided by K. Johnson, T. Rippietoe, M. Hearn, M. Amend, and the Army Corps of Engineers Field Research Facility. Physical oceanographic data were provided by Dr. S. Lentz, J. Largier and L. Brubaker, and the Army Corps of Engineers Field Research Facility. This research was supported by the National Science Foundation, Coastal Ocean Processes Grants OCE-9123514 and OCE-9633071.

\section{LITERATURE CITED}

Alexander SE, Roughgarden J (1996) Larval transport and population dynamics of intertidal barnacles: a coupled benthic/oceanic model. Ecol Monogr 66:259-275

Austin JA, Barth JA (2002) Drifter behavior on the Oregon-
Washington shelf during downwelling-favorable winds. J Phys Oceanogr 32:3132-3144

Austin JA, Lentz SJ (2002) The inner shelf response to winddriven upwelling and downwelling. J Phys Oceanogr 22: 2171-2193

Barber RT, Smith RL (1981) Coastal upwelling. In: Longhurst A (ed) Analysis of marine ecosystems. Academic, London, New York, p 31-67

Barth JA, Smith RL (1998) Separation of a coastral upwelling jet at Cape Blanco, Oregon, USA. S Afr J Mar Sci 19:5-14

Barth J, Pierce S, Smith R (2000) A separating coastal upwelling jet at Cape Blanco, Oregon and its connection to the California Current System. Deep-Sea Res II 47: $783-810$

Bousfield EL (1955) Ecological control of the occurrence of barnacles in the Miramichi Estuary. Natl Mus Can Bull 137:1-66

Broitman BR, Navarrete SA, Smith F, Gaines SD (2001) Geographic variation in southeastern Pacific intertidal communities. Mar Ecol Prog Ser 224:21-34

Chanley P, Andrews JD (1971) Aids for identification of bivalve larvae of Virginia. Malacologia 11:45-119

Chia FS, Buckland-Nicks J, Young CM (1984) Locomotion of marine invertebrate larvae: a review. Can J Zool 62: 1205-1222

Connell JH (1985) The consequences of variation in initial settlement vs. post-settlement mortality in rocky intertidal communities. J Exp Mar Biol Ecol 93:11-45

Connolly RS, Roughgarden J (1999) Increased recruitment of northeastern Pacific barnacles during the 1997 El Nino. Limnol Oceanogr 44:466-469

Connolly SR, Menge BA, Roughgarden J (2001) A latitudinal gradient in recruitment of intertidal invertebrates in the northeast Pacific Ocean. Ecology 82:1799-1813

Cragg SM (1980) Swimming behaviour of the larvae of Pecten maximus (L.) (Bivalvia). J Mar Biol Assoc UK 60:551-564

Csanady GT (1972a) The coastal boundary layer in Lake Ontario. II. The summer-fall regime. J Phys Oceanogr 2: 168-176

Csanady GT (1972b) The coastal boundary layer in Lake Ontario. I. The spring regime. J Phys Oceanogr 2:41-53

Csanady GT (1974) Mass exchange episodes in the coastal boundary layer, associated with current reversals. Rapp P-v Reun Cons Int Explor Mer 167:41-45

Cudaback CN, Largier JL (2001) The cross-shelf structure of wind-and buoyancy-driven circulation over the North Carolina inner shelf. Cont Shelf Res 21:1649-1668

de Wolf $P$ (1974) On the retention of marine larvae in estuaries. Thalassia Jugoslavica 10:415-424

Ebert TA, Russell MP (1988) Latitudinal variation in size structure of the west coast purple sea urchin: a correlation with headlands. Limnol Oceanogr 33:286-294

Farrell TM, Bracher D, Roughgarden J (1991) Cross-shelf transport causes recruitment to intertidal populations in central California. Limnol Oceanogr 36:279-288

Fiedler PC (1986) Offshore entrainment of anchovy by displacement eddy. Calif Coop Ocean Fish Investig Rep 77: 3248-3255

Franks PJS (1992) Sink or swim: accumulation of biomass at fronts. Mar Ecol Prog Ser 82:1-12

Franks PJS (1997) Spatial patterns in dense algal blooms. Limnol Oceanogr 42:1297-1305

Gaines SD, Bertness MD (1994) Does variable transport generate variable settlement in marine species? In: Dyer KR, Orth RJ (eds) Changes in fluxes in estuaries: implications from science and management. Olsen \& Olsen, Fredenborg, p 315-322 
Gaines SD, Brown S, Roughgarden J (1985) Spatial variation in larval concentrations as a cause of spatial variation in settlement for the barnacle Balanus glandula. Oecologia 67:267-272

Gallager SM, Bidwell JP, Kuzirian AM (1989) Strontium is required in artificial seawater for embryonic shell formation in two species of bivalve molluscs. In: Crick R (ed) Origin, evolution, and modern aspects of biomineralization in plants and animals. Plenum, New York

Garland ED, Zimmer CA, Lentz SJ (2002) Larval distributions in inner-shelf waters: the roles of wind-driven cross-shelf currents and diel vertical migrations. Limnol Oceanogr 47: 803-817

Genin A, Jaffe JS, Reef R, Richter C, Franks PJS (2005) Swimming against the flow: a mechanism of zooplankton aggregation. Science 308:860-862

Haury LR, Pelaez J, Koblinsky CJ, Wiesenhahan D (1986) Biological consequences of a recurrent eddy off Point Conception, California. J Geophys Res 91:12937-12956

Hidu H, Haskin HH (1978) Swimming speeds of oyster larvae Crassostrea virginica in different salinities and temperatures. Estuaries 1:252-255

Kamykowski D, Reed RE, Kirkpatrick GJ (1992) Comparison of sinking velocity, swimming velocity, rotation and path characteristics among six marine dinoflagellate species. Mar Biol 113:319-328

Largier J (2003) Considerations in estimating larval dispersal distances from oceanographic data. Ecol Appl 13:S71-S89

Lennert-Cody CE, Franks PJS (1999) Plankton patchiness in high-frequency internal waves. Mar Ecol Prog Ser 186: $59-66$

Loosanoff VL, Davis HC, Chanley PE (1966) Dimensions and shapes of larvae of some marine bivalve mollusks. Malacologia 4:351-435

Ma H (2001) Physical mechanisms and temporal and spatial patchiness in bivalve larval supply and settlement on the inner shelf of the Mid-Atlantic bight. PhD thesis, Rutgers University, New Brunswick, New Jersey

Mann R, Wolf CC (1983) Swimming behaviour of larvae of the ocean quahog Arctica islandica in response to pressure and temperature. Mar Ecol Prog Ser 13:211-218

Mann R, Campos BM, Luckenback MW (1991) Swimming rate and responses of larvae of three mactrid bivalves to salinity discontinuities. Mar Ecol Prog Ser 68:257-269

Menge BA (1991) Relative importance of recruitment and other causes of variation in rocky intertidal community structure. J Exp Mar Biol Ecol 146:69-100

Menge BA (2000) Top-down and bottom-up community regulation in marine rocky intertidal habitats. J Exp Mar Biol Ecol 250:257-289

Menge BA, Daley BA, Wheeler PA, Strub PT (1997) Rocky intertidal oceanography: an association between community structure and nearshore phytoplankton concentration. Limnol Oceanogr 42:57-66

Olsen DB, Backus RH (1985) The concentrating of organisms at fronts: a coldwater fish and a warm-core Gulf Stream ring. J Mar Res 43:113-137

Omori M, Ikeda T (1984) Methods in marine zooplankton ecology. Wiley, New York

Peterson WT, Miller CB, Hutchinson A (1979) Zonation and

Editorial responsibility: Antony Underwood (Contributing

Editor), Sydney, Australia maintenance of copepod populations in the Oregon upwelling zone. Deep Sea-Res 26A:467-494

Poulin E, Palma AT, Leiva G, Narvaez D, Pacheco R, Navarrete SA, Castilla JC (2002) Avoiding offshore transport of competent larvae during upwelling events: the case of the gastropod Concholepas concolepas in Central Chile. Limnol Oceanogr 47:1248-1255

Rees CB (1950) The identification and classification of lamellibranch larvae. Hull Bull Mar Ecol 3:73-104

Rennie S, Largier J, Lentz S (1999) Observations of a pulsed buoyancy current downstream of Chesapeake Bay. J Geophys Res 104:18227-18240

Roughgarden J, Gains SD, Possingham H (1988) Recruitment dynamics in complex life cycles. Science 241:1460-1466

Rumrill SS (1990) Natural mortality of marine invertebrate larvae. Ophelia 21:163-198

Shanks AL, Eckert G (2005) Population persistence of California Current fishes and benthic crustaceans: a marine drift paradox. Ecol Monogr 75(4):505-524

Shanks AL, Largier J, Brink L, Brubaker J, Hooff R (2002) Observations on the distribution of meroplankton during a downwelling event and associated intrusion of the Chesapeake Bay estuarine plume. J Plankton Res 24:391-416

Shanks AL, Largier J, Brubaker J (2003) Observations on the distribution of meroplankton during an upwelling event. J Plankton Res 25:645-667

Strub PT, James C (2000) Altimeter-derived variability of surface velocities in the California Current System: 2. Seasonal circulation and eddy statistics. Deep-Sea Res II 47 : 831-870

Sullivan CM (1948) Bivalve larvae of Malpeque Bay, P.E.I. Fish Res Bd Can Bull LXXVII:1-36

Thorson G (1946) Reproduction and larval development of Danish marine bottom invertebrates, with special reference to the planktonic larvae in the sound (Oresund). Medd Dan Fisk Havunders Ser Plank 4:1-523

Thorson G (1950) Reproduction and larval ecology of marine bottom invertebrates. Biol Rev 25:1-45

Underwood AJ (1981) Structure of a rocky intertidal community in New South Wales: patterns of vertical distribution and seasonal change. J Exp Mar Biol Ecol 51:57-85

Underwood AJ, Chapman MG (1996) Scales of spatial patterns of distributions of intertidal invertebrates. Oecologia 107: 212-224

Underwood AJ, Denley E (1984) Paradigms, explanations, and generalizations in models for the structure of intertidal communities on rocky shores. In: Strong DR, Simberloff D, Abele LG, Thistle AB (eds) Ecological communities: conceptual issues and the evidence. Princeton University Press, Princeton, NJ, p 151-180

Underwood AJ, Fairweather PG (1988) Supply-side ecology and benthic marine assemblages. Trends Ecol Evol 4: $16-20$

Venrick EL (1978) How many cells to count? In: Sournia A (ed) Phytoplankton manual. UNESCO, Paris, p 167-180

Waldorf BW, Largier JL, Rennie S, Austin J, Greengrove C (1995) Coastal Ocean Process (CoOP) Pilot Project Data Report: R/V Hatteras Shipboard Measurements. Underway, CTD and ADCP Data August 1994. Report No. SIO Reference Series No. 95-29, Scripps Institution of Oceanography, La Jolla, CA

Submitted: April 30, 2005; Accepted: July 12, 2005

Proofs received from author(s): October 5, 2005 